Journal of Clinical Investigation

Vol. 41, No. 11, 1962

\title{
EVALUATION OF VAGINAL SMEAR, SERUM GONADOTROPIN, PROTEIN-BOUND IODINE, AND THYROXINE-BINDING AS MEASURES OF PLACENTAL ADEQUACY *
}

\author{
By J. T. NICOLOFF, $\dagger$ R. NICOLOFF, $\ddagger$ AND J. T. DOWLING § \\ (From the Departments of Medicine, Veterans Administration Center and University of Cali- \\ fornia Medical Center, Los Angeles, and the Department of Obstetrics and \\ Gynecology, Kaiser Hospital, Hollywood, Calif.)
}

(Submitted for publication March 8, 1962; accepted July 19, 1962)

During pregnancy the characteristic increase in the thyroxine-binding capacity of the circulating globulin, TBG (1-3), is associated with a retarded rate of thyroxine turnover (4) and an increase in the concentration of hormonal iodine (PBI) in the plasma (1-4). These alterations in iodine metabolism have not been found in women with choriocarcinomas who excrete large quantities of chorionic gonadotropin (5), but do occur in nonpregnant individuals given large quantities of estrogens (6-8). It has been concluded, therefore, that during pregnancy these phenomena result from systemic effects of placental estrogens. Moreover, the sera of aborting women often fail to show the characteristic increase in serum PBI (9) and in thyroxine-binding by TBG (2).

In the past, attempts have been made to use the concentration of $\mathrm{PBI}$ as an indicator of fetal viability $(9,10)$; however, as appears to be true of studies of urinary or plasma chorionic gonadotropin determinations, pregnandiol and estrogen levels, and vaginal smears (11-15), the PBI has not proved satisfactory for routine use. It appeared possible, however, that assessment of TBG might prove of value as an indicator of placental function. For that reason a technique was developed for rapidly estimating serum thyroxinebinding, and its value in predicting the outcome

* Work supported by grant A-3000 from the National Institute of Arthritis and Metabolic Diseases, U. S. Public Health Service, grant T-154 from the American Cancer Society, and a grant-in-aid from the Permanente Foundation. Presented in part at the 1960 meeting of the Endocrine Society.

† Present address: Wadsworth General Hospital, VA Center, Los Angeles, California.

$\ddagger$ Present address: Kaiser Hospital, Hollywood, California.

$\S$ Present address: The King County Hospital System, Seattle, Washington. of pregnancy was compared with that of the PBI, serum chorionic gonadotropin, and the vaginal smear.

It was found that serum gonadotropin levels and assessment of the vaginal epithelium were poor prognostic indicators in early pregnancy. On the other hand, the parameter of serum thyroxinebinding, by virtue of its reproducibility and technical ease, appears to allow prediction of the outcome of most threatened abortions. ${ }^{1}$

\section{MATERIALS AND METHODS}

Measurement of serum $T B G$. Since a variety of ionexchange resins have been found to have a high affinity for thyroxine $(16,17)$, previously described methods for assessing serum thyroxine-binding (18-21) were adapted for quantitative assessment of TBG by using the anionic exchange resin, Dowex 2, A-G $2 \times 7,200$ to $400 \mathrm{mesh}$, obtained from a commercial supplier in the chloride form. The resin was converted to the maleate form in from 4 to 7 days by repeated washing with $0.2 \mathrm{M}$ Tris maleate buffer ( $\mathrm{pH} 8.6$ ) until no precipitate appeared in the supernatant fluid upon addition of a few drops of $0.1 \mathrm{M}$ silver nitrate. After repeated washing with distilled water and finally with acetone, the resin was dried in room air on a filter-paper pad in a Büchner funnel.

To establish optimal characteristics for the procedure, the effects of the quantity of resin employed, amount of serum, concentration of $\mathrm{PBI}, \mathrm{pH}$, and time of incubation on the resin uptake of labeled thyroxine were observed. The most useful preparation proved to be $100 \mathrm{mg}$ of dry resin incubated with $0.5 \mathrm{ml}$ of serum which contained $0.1 \mu \mathrm{c}$ of $\mathrm{I}^{131}$-labeled thyroxine and $0.19 \mu \mathrm{g}$ of stable thyroxine. The latter was added to reduce variations due to differences in endogenous thyroxine content. The resin was weighed into tared counting tubes with a semi-automatic balance, and the labeled serum was added directly to the tube. The resin serum mix-

1 The more general term, serum thyroxine-binding, has been used here interchangeably with TBG for convenience without implying a necessary identity with thyroxine-binding by whole serum or by specific thyroxinebinding proteins determined by other methods. 
ture was incubated at room temperature with a shaking rate of 80 strokes per minute. Since it was found that $\mathrm{pH}$ values ranging from 7.0 to 8.6 had no appreciable effect on the resin uptake of thyroxine from serum, subsequent experiments did not require adjustment of serum $\mathrm{pH}$. Time curves were performed under the foregoing conditions, which indicated that the maximum difference between the uptake of thyroxine from pregnancy sera and from normal sera occurred after five to ten minutes of incubation. Nearly complete uptake of the hormone from either pregnancy or normal sera occurred after from 4 to 6 hours. A ten-minute period of incubation was selected as the optimal time for demonstrating differences in serum thyroxine-binding. For purposes of control, resin uptakes of thyroxine from pooled, normal sera and pooled, normal, pregnancy sera were determined during all studies of experimental sera. All studies were performed in duplicate. After exactly ten minutes of incubation, $5 \mathrm{ml}$ of distilled water was promptly added to the tube from a wash bottle and the resin was sedimented by centrifugation at $3,000 \mathrm{rpm}$ for 2 to 3 minutes. The supernatant fluid was removed by aspiration, and the washing procedure was repeated 3 more times with $5 \mathrm{ml}$ of water. The tube was then counted in a well-type scintillation counter. Thyroxine-binding was arbitrarily expressed as the decimal ratio obtained by dividing the net counts per minute accumulated from the control serum by the net counts accumulated from the experimental serum. Thus, the normal value was 1.0, increased thyroxine-binding was indicated by values greater than 1.0 , and reduced binding by values less than 1.0. These values are referred to herein as the "resin uptake ratio."

To establish the validity of the resin uptake ratio as a measure of thyroxine-binding by TBG, replicate studies were made of the resin uptake and of the electrophoretically determined saturation capacities of TBG in 71 subjects who exhibited wide variations in thyroxine-binding by TBG (Figure 1). The electrophoretic method employed was as described elsewhere $(4,8,22,23)$. This consisted briefly of the addition of tracer thyroxine to serum, enrichment of samples of the labeled serum with stable thyroxine to six concentrations $(10,40,120,230$, 340 , and $450 \mu \mathrm{g}$ per cent), ${ }^{2}$ and zonal electrophoresis of $0.020 \mathrm{ml}$ samples of each portion on filter-paper (What-

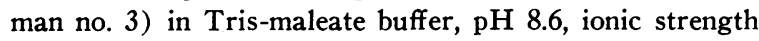
0.10 at $140 \mathrm{v}$ for 16 hours. The quantities of total radioactivity associated with TBG and TBPA (thyroxinebinding prealbumin) were then assessed at each concentration of added thyroxine. Saturation capacities of the proteins for thyroxine were determined from these data. In the study group was one euthyroid subject with remarkably subnormal serum thyroxine-binding and concentration of PBI (24), and members of a family in

2 The present concentrations of added thyroxine proved to be more suitable than other suggested concentrations (23) in comparing sera that exhibited an extreme range of saturation capacity of TBG (4 to $62 \mu \mathrm{g}$ per cent thyroxine).

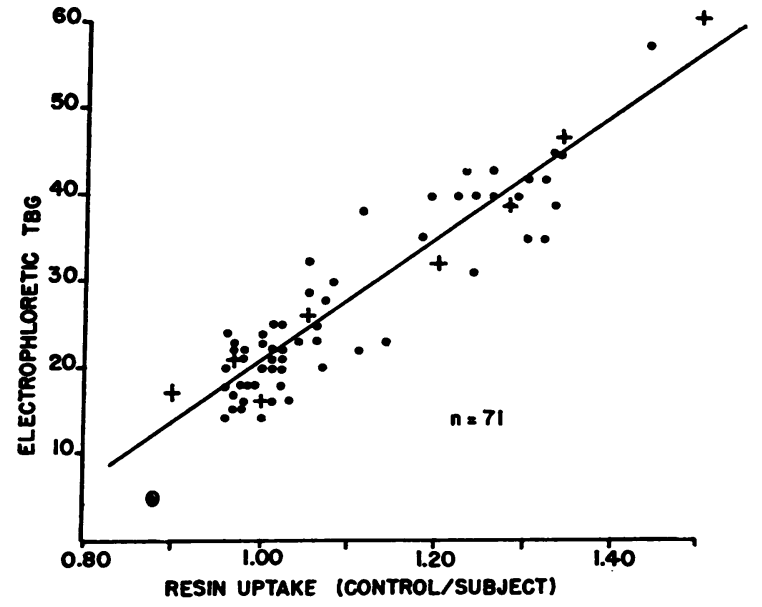

Fig. 1. Comparison of the determination of SeRUM THYROXINE-BINDING BY ZONAL ELECTROPHORETIC AND ION-EXCHANGE RESIN TECHNIQUES. The crosses represent members of a family, four of whom exhibited idiopathic increases in thyroxine-binding by TBG. The point enclosed by a circle represents an isolated instance of reduced thyroxine-binding by TBG. Ordinate: saturation capacity, $\mu \mathrm{g}$ per cent thyroxine. Abscissa: resin uptake ratios, net counts per minute from control serum/net counts per minute from experimental serum.

whom representatives from three generations exhibited idiopathic increases in TBG $(25,26)$. Many individuals were selected who exhibited abnormally low thyroxine-binding capacities of TBPA $(20,22)$, or moderate hypoalbuminemia. The correlation coefficient between these methods was $0.92(\mathrm{p}<0.001)$. Altered binding by TBPA, or moderate hypoalbuminemia, did not affect the estimates. The linear regression equation derived from these data was $x=72.224 y-51.3$. If we assume continued linearity, the absence of thyroxine-binding by TBG would thus be represented by a theoretical resin uptake ration of 0.71 .

Sera were prepared from blood obtained from 103 normally pregnant women in various stages of pregnancy in order to establish normal ranges for subsequent comparisons of experimental data. Experimental sera were obtained from 78 patients during the pathologic pregnancies described in Table $I$ and in the subsequent figures. These women were grouped according to accepted clinical criteria without regard to similarities or differences in the etiology or pathogenesis of their disorders.

Other measures of pregnancy status. Quantitative serum gonadotropin levels were assayed by the male frog technique (27). ${ }^{3}$ To assure accuracy and reproducibility, sera were stored in the frozen state and tested in large numbers when seasonal variations in the frogs were mini-

${ }^{3}$ Kindly performed by Ronald Edwards, Gregory Wright, and Laura Austin of the Clinical Laboratory of the Kaiser Hospital, Los Angeles. 
J. T. NICOLOFF, R. NICOLOFF, AND J. T. DOWLING

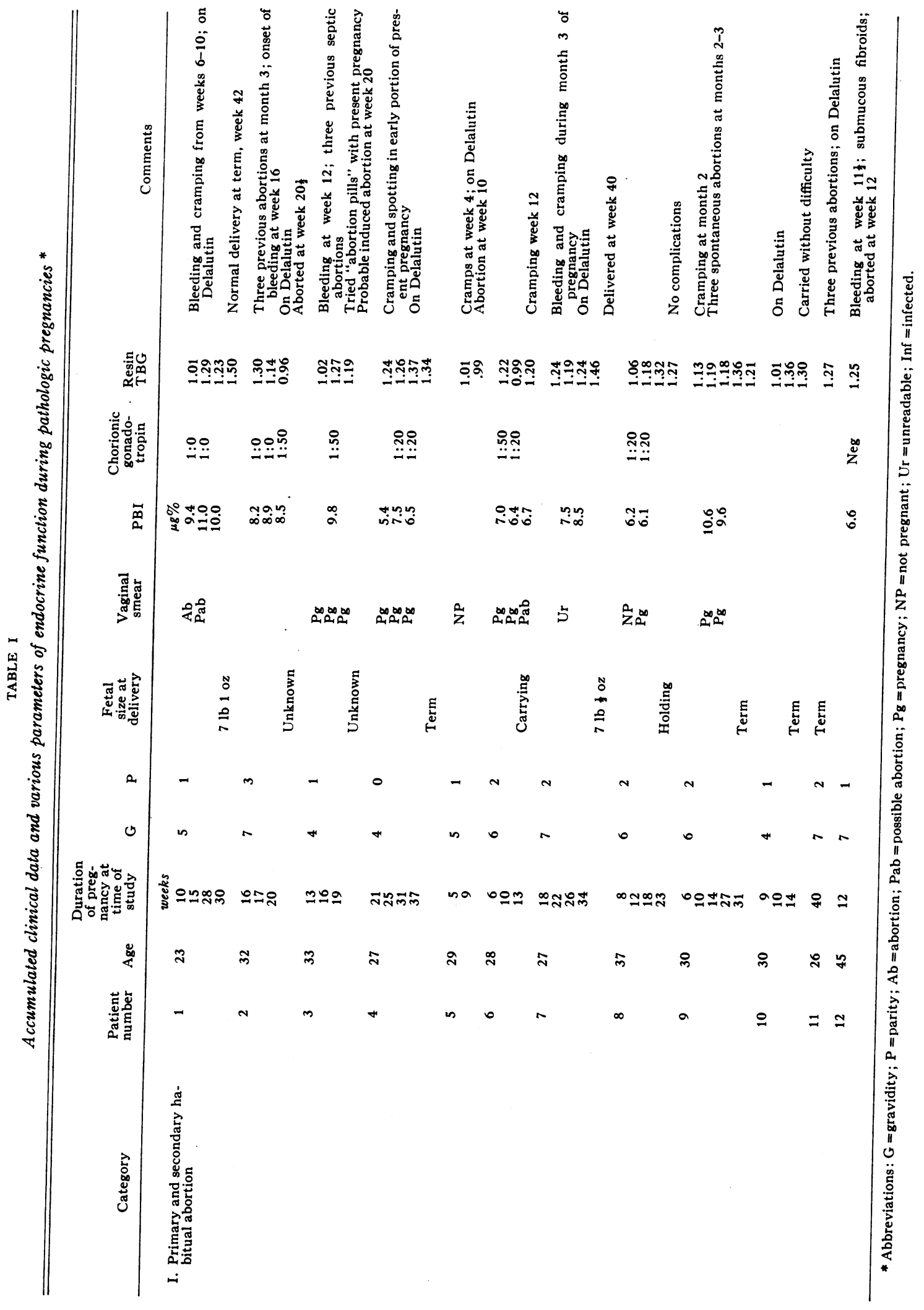




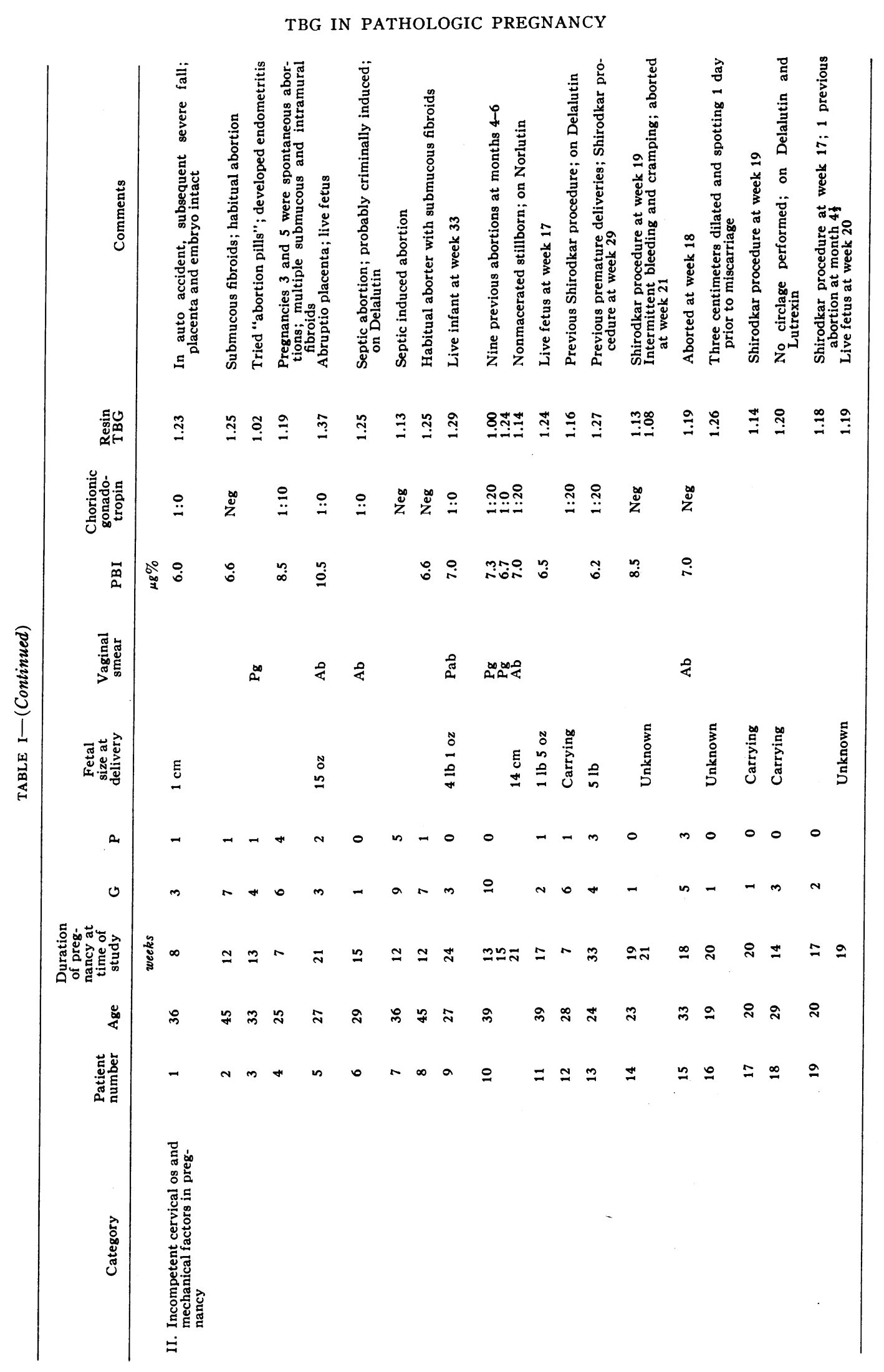




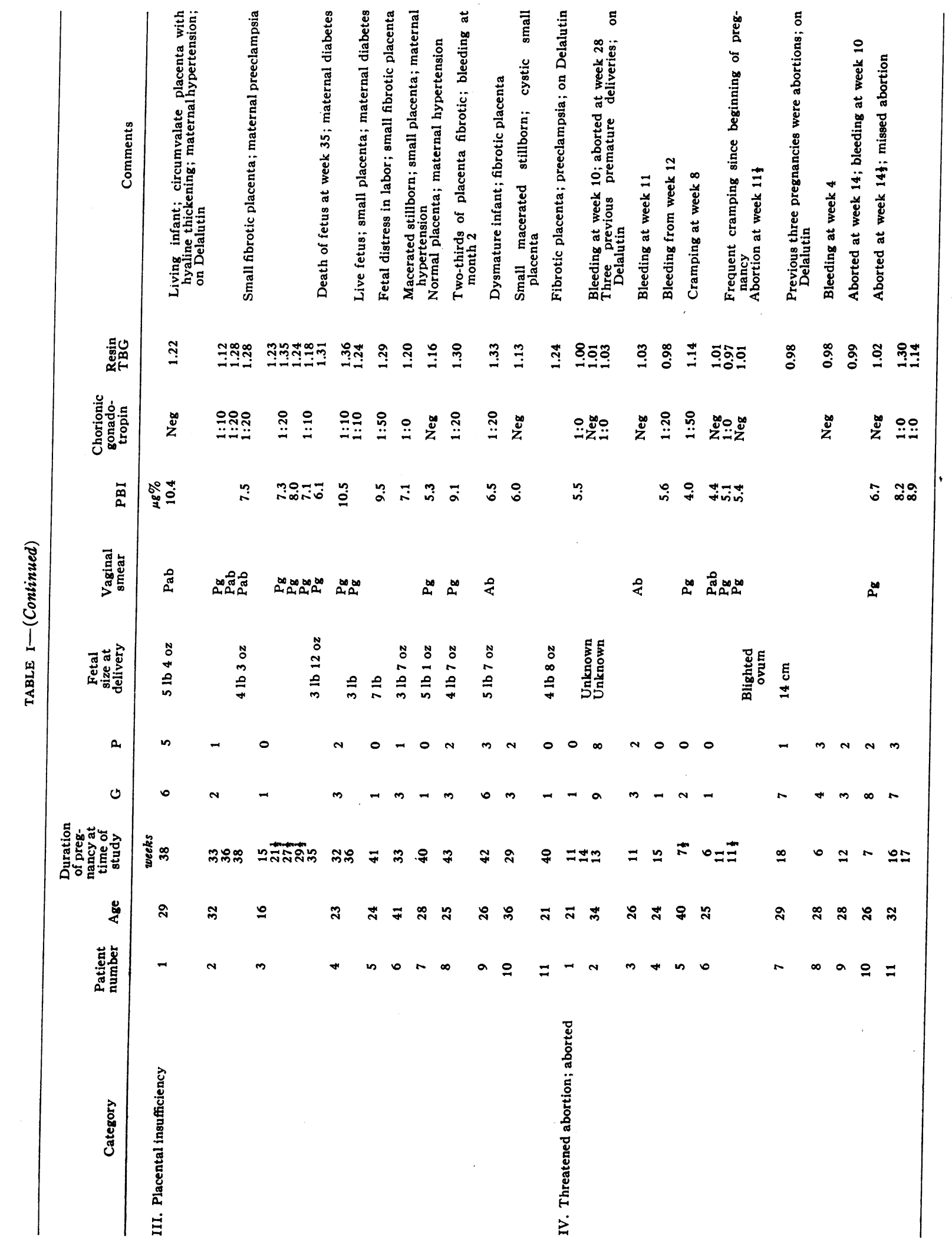


TBG IN PATHOLOGIC PREGNANCY

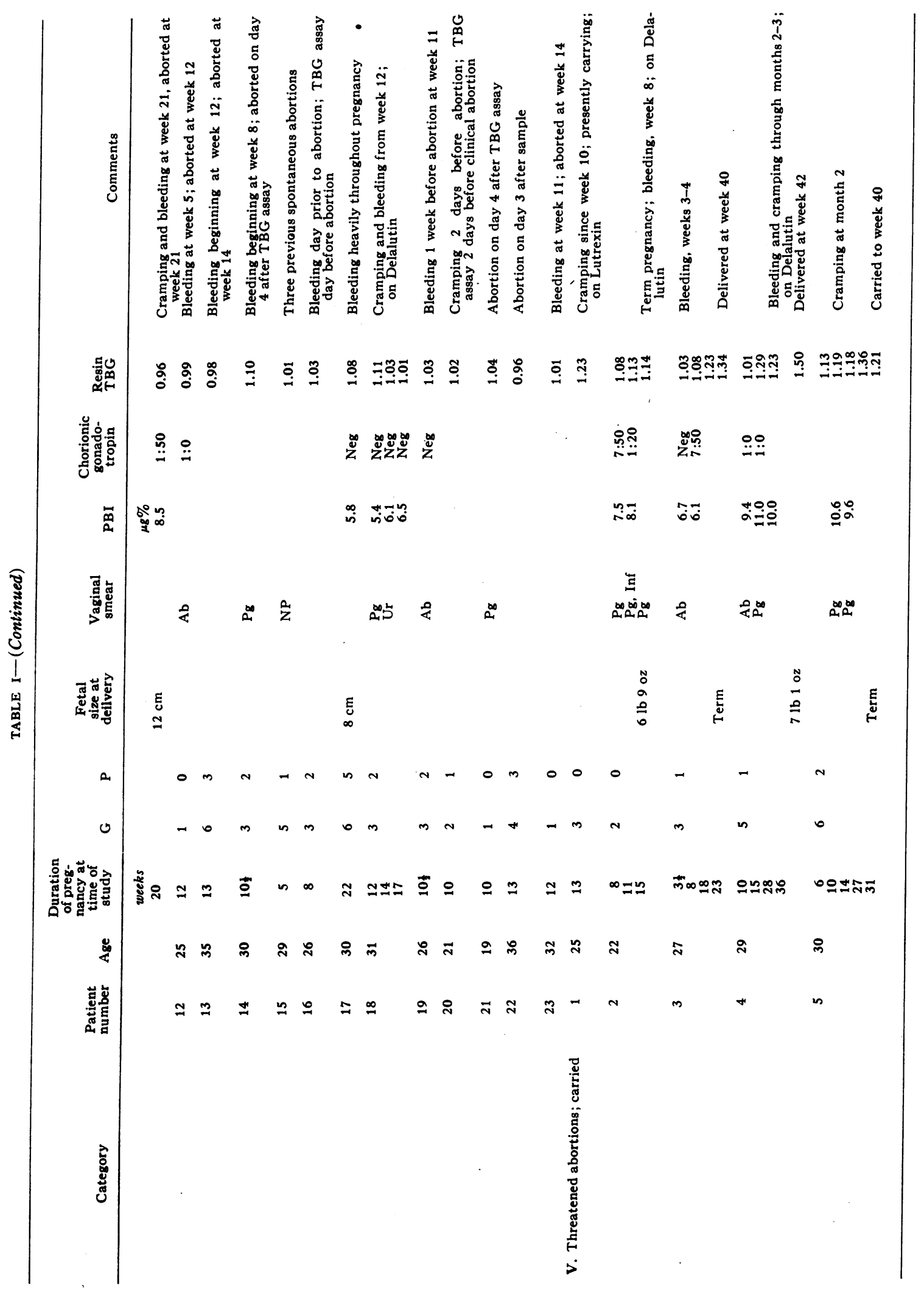


J. T. NICOLOFF, R. NICOLOFF, AND J. T. DOWLING

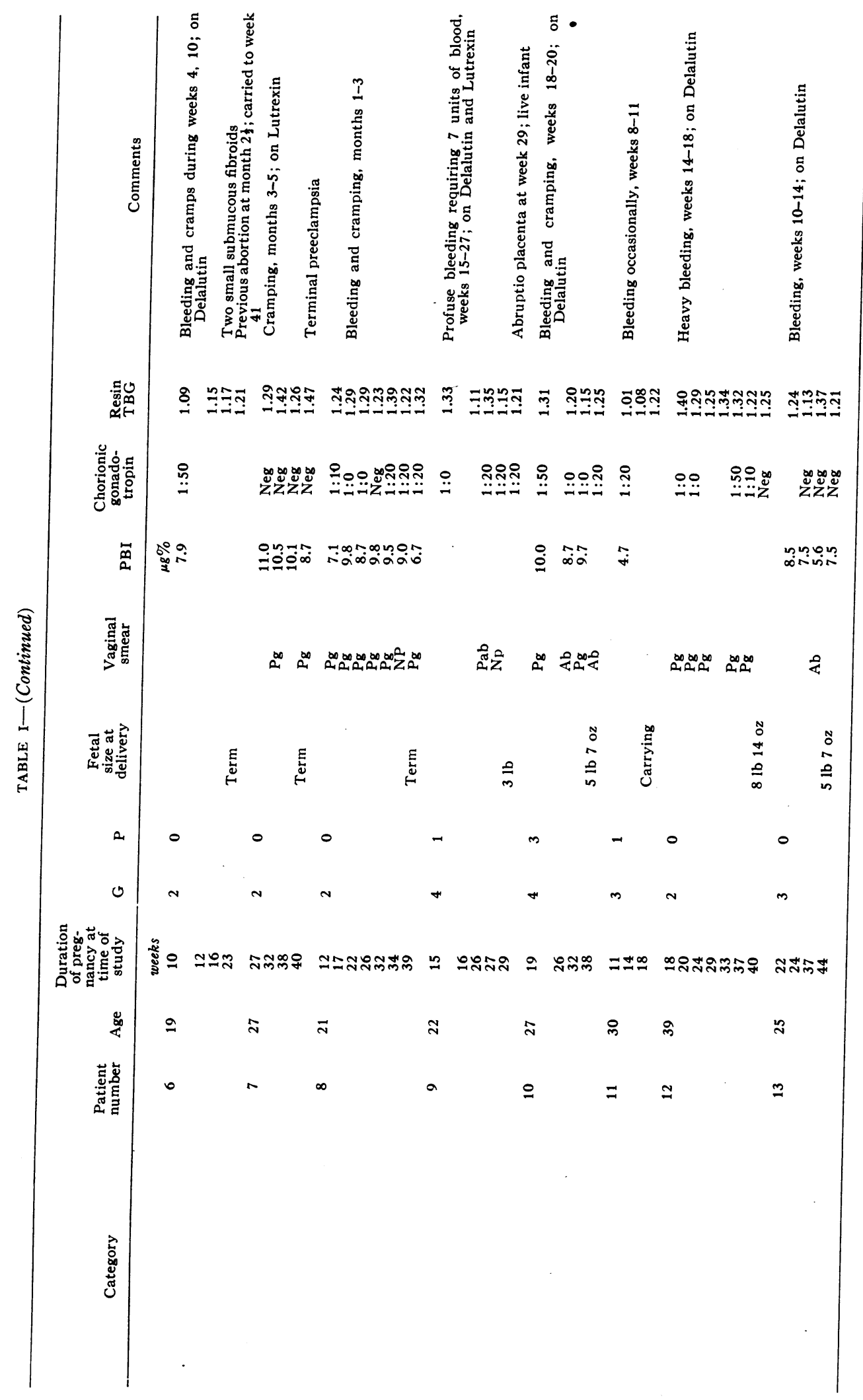


mal. Results were expressed as the greatest dilution of serum at which a positive result was obtained.

Vaginal epithelial changes were appraised by techniques described by Benson and Traut (28) for estrogenic, progestational, and abortion effects. These were read as unknowns by two examiners independently and classified into the following categories: not pregnant, pregnant, possible abortion, abortion, infected, and unreadable. A final reading was agreed upon by the examiners, and the evaluation was assigned to the proper patient and date.

Sera were accumulated in the frozen state for subsequent simultaneous determination of concentrations of serum PBI with the same reagents used. ${ }^{3}$

\section{RESULTS}

Control group. The resin uptake ratios of the 103 sera obtained at various intervals during the course of normal pregnancy are depicted in Figure 2. The inclosed area encompasses one standard deviation from the interval mean obtained from values accumulated over 5 -week periods. Although significant alterations in the resin uptake ratio occurred as early as the fifth week, it was not until ten weeks that consistent elevations were noted. Thereafter there was a gradual increase in the resin uptake ratio to the time of delivery.

Habitual abortion. This group of 12 women with a history of primary (three or more consecutive abortions without previous, viable pregnancies) or secondary (three or more consecutive abortions following the last viable pregnancy) habitual abortions was studied in a prospective

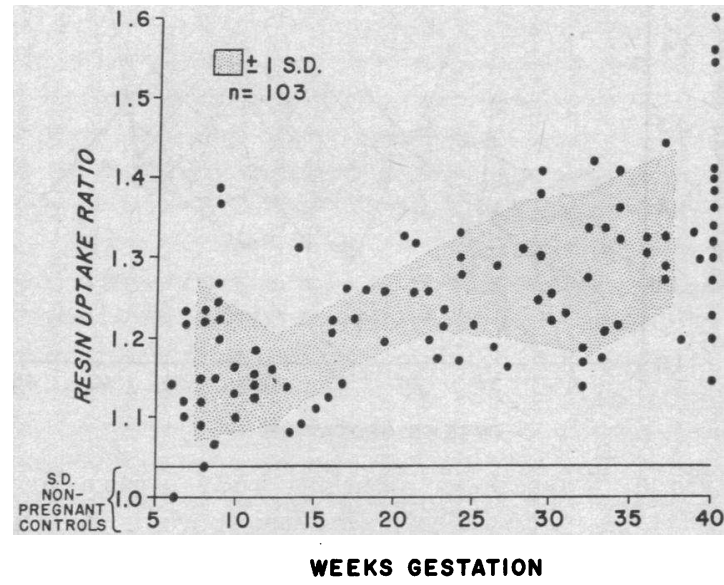

Fig. 2. Standard deviation from interval aVerages OF TBG LEVELS DURING NORMAL PREgNANCY BY THE RESIN METHOD. Individual values derived from duplicate determinations performed on sera obtained from weeks 6 to 40 of pregnancy.

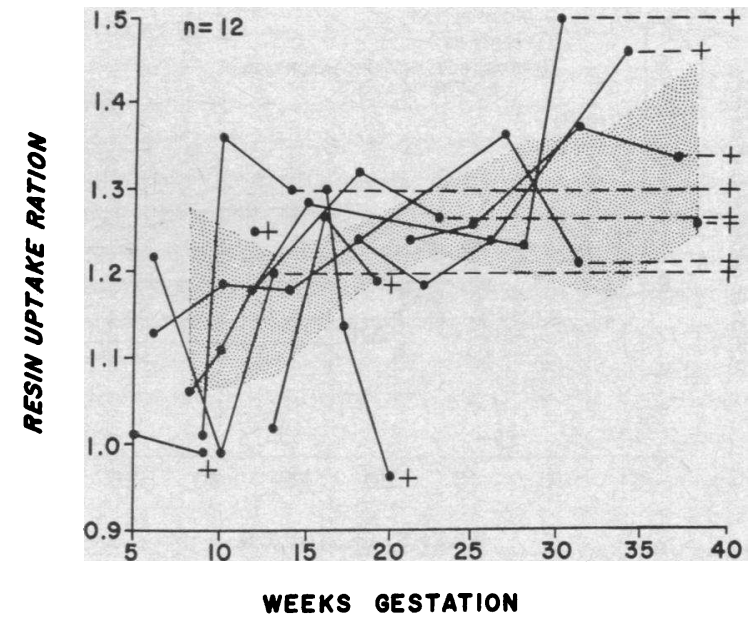

Fig. 3. Primary and Secondary habitual abortion GROUP. The cross indicates the time when the conceptus was delivered. Of the 12 patients studied, 8 carried to normal term deliveries; of the 4 who aborted, one did so after loss of normal pregnancy changes, one failed to develop pregnancy changes, and the remaining two aborted despite the finding of normal pregnancy changes in thyroxine-binding. Mechanical factors were suspected in these cases (induced abortion and submucous fibroids, respectively).

manner during the course of pregnancy (Figure 3 and Table I). Despite a high expectation of frequent abortions in this group, only 4 of the 12 failed to carry to viable births. Moreover, two of the abortions may have resulted from mechanical factors (Patients 3 and 12, Table I, Category I).

Patient 2 (Table I) probably terminated her pregnancy at 16 weeks at the time of uterine bleeding. Subsequently, her resin uptake ratio decreased over the next four weeks and she aborted at $201 / 2$ weeks. Patient 5 had a similar sequence of clinical events except that her serum never revealed pregnancy changes in resin uptake.

In contrast, Patient 3 , in whom there was evidence of self-induction, had normal pregnancy changes at 16 weeks after an initial low level at 13 weeks (at which time she was threatening to abort). At 19 weeks her resin ratio was still normal for pregnancy, although it had decreased sharply. She aborted at 20 weeks. In a similar manner, Patient 12 , in whom submucous fibroids were present, also aborted when her resin uptake ratio was at pregnancy levels. Of the eight women who carried, seven noticed lower abdominal cramping or bleeding, or both, despite their displaying 


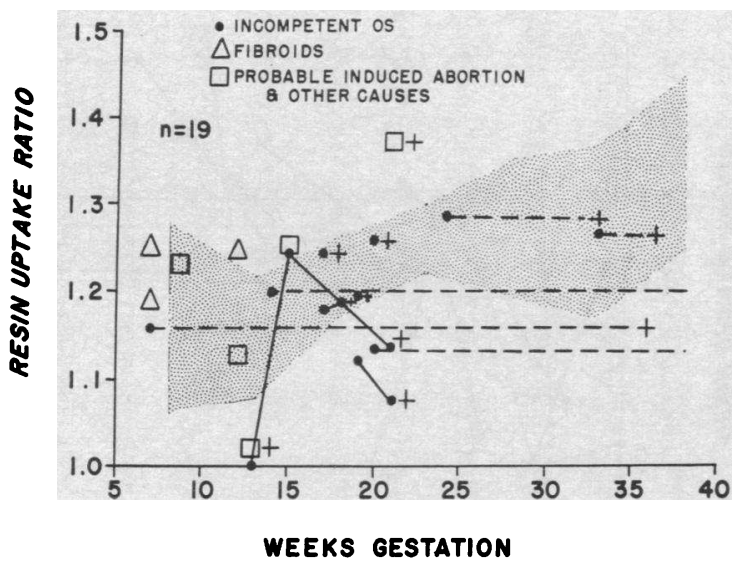

Fig. 4. INCOMPETENT CERVICAL OS AND OTHER MECHANICAL FACTORS IN PREGNANCY. A cross indicates when the conceptus was delivered. Where there is no cross, delivery occurred shortly after the sample was obtained. Five of these 19 women carried their pregnancies to term, and these were patients with incompetent cervical os. Of the remaining women, all but 3 aborted despite the finding of normal pregnancy changes in serum thyroxine-binding. Of the 3 who exhibited abnormal thyroxine-binding, one had earlier shown normal pregnancy changes.

resin uptake ratios characteristic of normal pregnancy.

Incompetent cervical os and other mechanical factors in pregnancy. These 19 women exhibited a variety of abnormal clinical states in which there was the common denominator of an intra-uterine abnormality which was either present before or acquired during pregnancy (Figure 4; Table I, Category II). These consisted of submucous fibroids (Patients 2, 4, 8), abruptio placenta ( $\mathrm{Pa}-$ tient 5), probable traumatic expulsion of the conceptus (Patient 1 ), incompetent cervical os ( $\mathrm{Pa}$ tients 9 through 19) and probable self-induced abortions (Patients 3, 6, 7). Five of them, all with a diagnosis of incompetent os, carried to term. All but one of the remainder showed normal increases in thyroxine-binding. This exception was Patient 14, in whom a circlage of the uterine cervix (Shirodkar procedure) was performed which probably delayed clinical evidence of an otherwise immediate termination of her pregnancy.

Placental insufficiency. These 11 women were patients in late pregnancy in whom gross pathology of the placenta, and often, secondary alterations of the fetus were found (Figure 5; Table I, Cate-

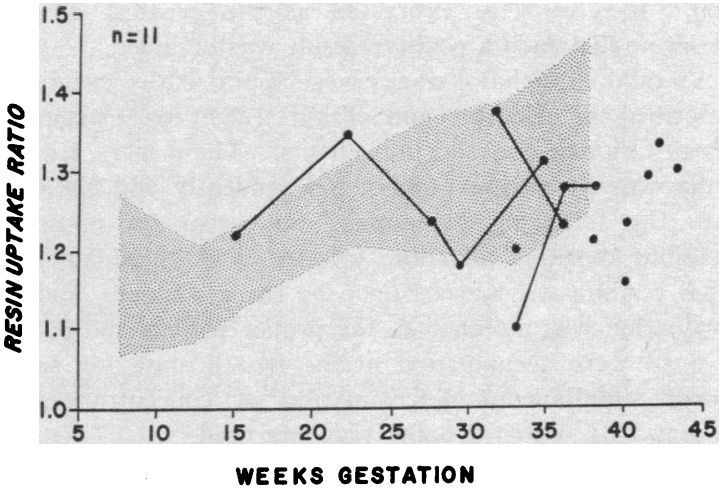

Fig. 5. Placental insufficiency. Delivery of the conceptus occurred shortly after the last sample was obtained. Relatively normal values were found, even in the presence of infarction of two-thirds of the placenta ( $\mathrm{Pa}$ tient 8, Table I).

gory III). Hypertension, vascular disease, diabetes, and preeclampsia constituted the predominant underlying disorders.

Despite as much as two-thirds infarction of the placenta, pregnancy values of resin uptake were noted in these women. When the data were compared with control values during this period, however, resin uptake values were statistically lower than expected $(\mathrm{p}<0.05)$.

Threatened abortions in early pregnancy. Thirty-six cases of threatened abortion were stud-

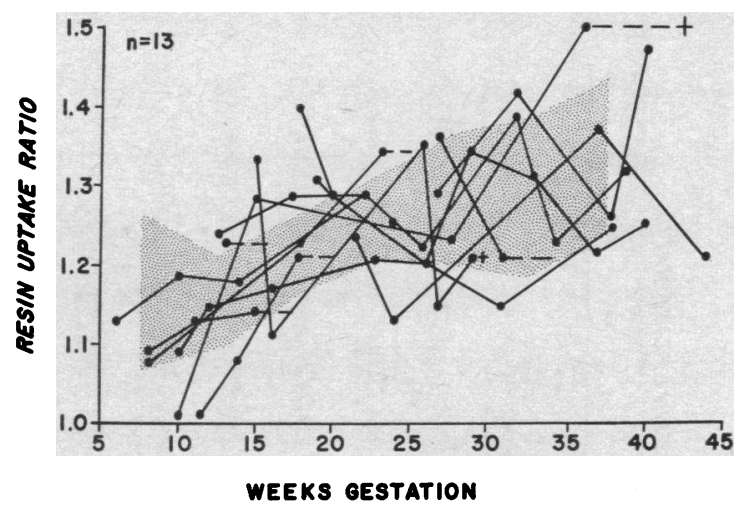

Fig. 6. Threatened abortions that Carried to A LIVE FETUS. Cross denotes the time at which the fetus was delivered. Despite the clinical history of threatened abortion and in some cases a history of copious bleeding throughout pregnancy, only one woman is known to have delivered prematurely. Two women with low initial values for serum thyroxine-binding reassuringly exhibited progressive increases into the normal pregnancy range at follow-up. 
ied in whom 13 carried to a viable pregnancy (Figure 6; Table I, Category V), and 23 spontaneously aborted from unknown causes (Figure 7; Table I, Category IV). In the former group, normal pregnancy changes in resin uptake ratio were noted throughout pregnancy in those patients who were followed. In the latter group, initial values were in the nonpregnant range or rapidly became so during follow-up in all but two instances. Differences between either the initial or the final values of the aborting group and the pregnant control values were highly significant ( $\mathrm{p}<0.001)$.

Results of ancillary methods for evaluating the status of pregnancy. Assessment of the vaginal epithelium and titers of serum chorionic gonadotropin poorly predicted the outcome of pregnancy except in the case of known mechanical causes of gestational failure or in placental insufficiency (Table II). Low or absent titers correctly predicted failures in 10 of 12 instances, whereas serum thyroxine-binding was abnormal in only 2 of 19 patients studied. On the other hand, gonadotropin titers predicted failures in 3 of 10 women

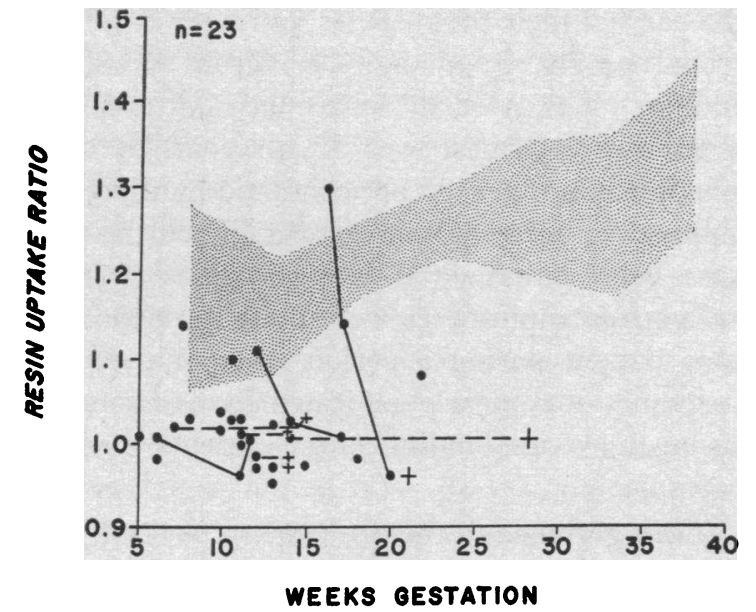

Fig. 7. Threatened ABortions that terminated IN ABORTION. Patient aborted shortly after the last value was obtained (see Table I) unless later termination is indicated by a dashed line and cross. These latter six women had pregnancies classified as missed abortion. One of these terminated 14 weeks after two consecutive values for serum thyroxine-binding were in the nonpregnant range. Only 2 of these 23 women who had no known cause for fetal wastage aborted after exhibiting normal pregnancy changes in serum thyroxine-binding (Patients 5 and 14 of this category, Table I).

TABLE II

Predictive value of vaginal smears, chorionic gonadotropin titers, and serum thyroxine-binding in the prognosis of pregnancy

\begin{tabular}{|c|c|c|c|c|c|c|c|}
\hline \multirow[b]{2}{*}{ Category } & \multirow[b]{2}{*}{ Outcome } & \multicolumn{2}{|c|}{ Vaginal smear } & \multicolumn{2}{|c|}{ Gonadotropin } & \multicolumn{2}{|c|}{ Resin TBG } \\
\hline & & $\begin{array}{l}\text { No. } \\
\text { correctly } \\
\text { predicted* }\end{array}$ & $\begin{array}{l}\text { Total no. } \\
\text { of studies }\end{array}$ & $\begin{array}{l}\text { No. } \\
\text { correctly } \\
\text { predicted* }\end{array}$ & $\begin{array}{l}\text { Total no. } \\
\text { of studies }\end{array}$ & $\begin{array}{l}\text { No. } \\
\text { correctly } \\
\text { predicted* }\end{array}$ & $\begin{array}{l}\text { Total no. } \\
\text { of studies }\end{array}$ \\
\hline \multirow{2}{*}{$\begin{array}{l}\text { I. Primary and sec- } \\
\text { ondary habitual } \\
\text { abortion }\end{array}$} & Aborted & 1 & 2 & 1 & 3 & 3 & 3 \\
\hline & Carried & 3 & 5 & 3 & 4 & 9 & 9 \\
\hline \multirow{2}{*}{$\begin{array}{l}\text { II. Incompetent os } \\
\text { and mechanical } \\
\text { factors }\end{array}$} & Aborted & 4 & 5 & 8 & 10 & 2 & 16 \\
\hline & Carried & 0 & 1 & 2 & 3 & 3 & 3 \\
\hline \multirow{2}{*}{$\begin{array}{l}\text { III. Placental } \\
\text { insufficiency }\end{array}$} & $\begin{array}{l}\text { Aborted (or } \\
\text { stillborn) }\end{array}$ & 0 & 1 & 2 & 2 & 0 & 3 \\
\hline & Carried & 3 & 6 & 5 & 7 & 8 & 8 \\
\hline $\begin{array}{l}\text { IV. Threatened } \\
\text { abortion }\end{array}$ & Aborted & 4 & 10 & 10 & 13 & 21 & 23 \\
\hline $\begin{array}{l}\text { V. Threatened } \\
\text { abortion }\end{array}$ & Carried & 6 & 10 & 7 & 11 & 13 & 13 \\
\hline Total aborted & & 9 & 18 & 21 & 28 & 26 & 45 \\
\hline Total carried & & 12 & 22 & 17 & 25 & 33 & 33 \\
\hline Total & & 21 & $40(52 \%)$ & 38 & $53(72 \%)$ & 59 & $78(76 \%)$ \\
\hline $\begin{array}{l}\text { Total for categories } \\
\mathrm{I}, \mathrm{IV} \text {, and V }\end{array}$ & & 14 & $27(52 \%)$ & 21 & $31(68 \%)$ & 46 & $48(96 \%)$ \\
\hline
\end{tabular}

* Based on values obtained nearest the date of abortion. 
who carried their pregnancies and were exhibiting normal pregnancy changes in serum thyroxinebinding. The over-all correctness of prediction by the vaginal smear was 52 per cent, by serum gonadotropin titers, 75 per cent, and by thyroxinebinding, 76 per cent. Moreover, it will be noted from Table I that serial determinations of smears and gonadotropin titers were quite variable in the same patient during a period when the status of pregnancy was clearly indicated by assessment of serum thyroxine-binding (e.g., Patients 8 and 10, Category V).

More germane to the comparison of these methods to the resin technique were the results obtained in the case of women who were threatening to abort who had no known causes for abortion and who either aborted or carried (Table I, Categories I, IV, and V). In these groups, comprising 48 patients, vaginal smears were assessed in 27 , and gonadotropin titers were measured in 31 . A correct prediction was made by the vaginal smear in only half the cases and by the gonadotropin titers in about two-thirds of the cases. The resin technique correctly predicted the outcome in 46 of 48 pregnancies, or 96 per cent.

The concentration of serum PBI, as noted by others, correlated moderately well with clinical status $(9,10)$. After 10 weeks of pregnancy, concentrations of serum PBI in women who threatened to abort and shortly did so were somewhat lower than concentrations in women who threatened to abort, but carried to delivery of viable infants $(p<0.02)$. When the same groups were compared on the basis of their resin uptake ratios, however, the difference proved to be of much greater significance $(\mathrm{p}<0.001)$.

\section{DISCUSSION}

Measurement of the accumulation of labeled thyroxine from serum by an anionic ion-exchange resin is a simple and rapid technique for appraising thyroxine-binding by the serum thyroxinebinding globulin (TBG) (18-21). When applied to a specific clinical problem, it proved to be a practical method for predicting the eventual outcome of pregnancy in women who were threatening to abort. In the present study it was a more reliable indicator of the prognosis of threatened abortion than previously described techniques, in- cluding the evaluation of the vaginal smear and measurement of serum gonadotropin titers. In late pregnancy, however, the finding of low or absent serum gonadotropin titers despite normal pregnancy changes in TBG appears to carry an ominous prognosis for pregnancy. Since the concentration of serum PBI is a function of several variables (29-33), it correlated only moderately well with the status of pregnancy $(9,10)$.

Beyond its clinical application, measurement of the resin uptake of serum thyroxine clarifies certain physiologic events that occur in pathologic pregnancies. Previous work has shown that both the concentration of $\mathrm{PBI}$ and thyroxine-binding by TBG return slowly to normal after pregnancy or after discontinuing the administration of large amounts of estrogen, and achieve nonpregnant values only after from 3 to 6 weeks $(2,6)$. This gradual decrease was observed in one woman in the habitual abortion group (Patient 2, Table I, Category I) and in two patients in the threatened abortion group (Patients 11 and 18, Table I, Category IV). Thus, it is likely that placental failure to elaborate normal amounts of estrogen would not be reflected by a decreased resin uptake ratio for at least several days. Accordingly, most women who were threatening to abort and who later did so may have incurred placental failure as long as several weeks before the event of abortion. This interpretation agrees with the conclusion of a number of workers who have found evidence that fetal death occurs approximately six weeks prior to abortion (34-36). On the other hand, a number of women with known mechanical causes of gestational failure, such as incompetent cervical os, submucous leiomyomata, abruptio placenta, and induced abortion may exhibit initially adequate elaboration of estrogen, as judged by normal pregnancy levels of serum thyroxine-binding. This finding indicates that death of the conceptus is a late event in these types of abortion. Moreover, it follows that the finding of normal pregnancy levels of TBG in patients who soon abort suggests search for such mechanical factors even though they are not clinically evident. If these patients are excluded from the group of women who are threatening to abort, then failure to find normal pregnancy TBG changes or loss of these changes confirms gestational failure and inevitable abortion regardless of the patient's apparent clini- 
cal course. Alternatively, in the absence of the foregoing disorders, women threatening to abort, regardless of their clinical course, who continuously exhibit normal pregnancy changes in TBG are likely to continue pregnancy at least to theoretical fetal viability and in most cases to term.

In no way should it be construed that this work indicates that placental failure to elaborate normal amounts of estrogen or abnormalities of thyroid function are causes of gestational failure. These data suggest that abortion results from prior death of the conceptus and that in most, if not all cases of threatened abortion, therapy with exogenous estrogen cannot be of benefit $(34,35)$. It is also apparent that estrogenic treatment would vitiate assessment of serum TBG as a method for following the course of pregnancy.

Many of the present women, particularly those with a diagnosis of habitual abortion, received relaxin or progestational steroids throughout the study-norethindrone (Norlutin) and hydroxyprogesterone caproate (Delalutin). These preparations appeared to have no effect on serum thyroxine-binding and therefore did not vitiate the predictive value of the assessment of serum TBG by the resin method. It is parenthetically noteworthy that despite previous suggestions (37, 38 ), the present data support the view that the arbitrary diagnosis of habitual abortion is artificial and misleading (39). In the prospective study of 12 women with this diagnosis, only 4 failed to carry to term and mechanical causes of abortion were suspected in two of these. Notable also was the fact that these women did respond to the stimulus of pregnancy with normal changes in thyroxine transport.

It is likely that techniques for assessing serum thyroxine-binding can be considerably improved. Such an attempt, with the use of immunochemical techniques, is currently under study. Measurement of changes in other circulating transport proteins may also be of value in following the status of pregnancy. It has been shown that plasma cortisol levels, the cortisol-binding protein (transcortin), ceruloplasmin, iron-binding globulin, and haptoglobin are all increased during the administration of large amounts of estrogen or during normal pregnancy (35-44). It is likely that a combined assessment of one or more of these transport proteins and of other parameters, such as gonadotropin titers, will allow improved prediction of the outcome of disturbed pregnancies. Moreover, the profile of results obtained may direct diagnostic attention toward specific pathogeneses of gestational failure.

\section{SUM MARY}

Studies of serum thyroxine-binding employing zonal electrophoresis and a technically simple ionexchange resin method correlated favorably and thereby allowed clinical evaluation of serum thyroxine-binding as an indicator of fetal viability.

Comparison of the method with assessments of protein-bound iodine, serum chorionic gonadotropin, and vaginal smears indicated its greater precision in predicting the outcome of threatened abortions.

Studies of 103 normally pregnant women and 78 patients during pathologic pregnancies suggested that normal pregnancy changes, in the absence of mechanical disturbances to gestation, were prognostically favorable in women who were threatening to abort.

These data confirm the view that fetal death considerably antidates clinical abortion in women whose pregnancies terminate after threatening to abort.

\section{ACKNOWLEDGMENT}

The authors wish to express their gratitude for the technical assistance of Mrs. Dzidra Razevska.

\section{ADDENDUM}

The similar findings of Brody and Carlström, derived from studies of pathologic pregnancies by an immunologic assay for human chorionic gonadotropin, have been recently published (45).

\section{REFERENCES}

1. Dowling, J. T., Freinkel, N., and Ingbar, S. H. Thyroxine-binding by sera of pregnant women. J. clin. Endocr. 1956, 16, 280.

2. Dowling, J. T., Freinkel, N., and Ingbar, S. H. Thyroxine-binding by sera of pregnant women, new-born infants, and women with spontaneous abortion. J. clin. Invest. 1956, 35, 1263.

3. Robbins, J., and Nelson, J. H. Thyroxine-binding by serum protein in pregnancy and in the newborn. J. clin. Invest. 1958, 37, 153.

4. Dowling, J. T., Hutchinson, D. L., Hindle, W. R., and Kleeman, C. R. Effects of pregnancy on iodine metabolism in the primate. J. clin. Endocr. 1961, 21, 779. 
5. Dowling, J. T., Freinkel, N., and Ingbar, S. H. Iodine metabolism in hydatidiform mole and choriocarcinoma. J. clin. Endocr. 1960, 20, 1.

6. Dowling, J. T., Freinkel, N., and Ingbar, S. H. Effect of diethylstilbestrol on the binding of thyroxine in serum. J. clin. Endocr. 1956, 16, 1491.

7. Engbring, N. H., and Engstrom, W. W. Effects of estrogen and testosterone on circulating thyroid hormone. J. clin. Endocr. 1959, 19, 783.

8. Dowling, J. T., Freinkel, N., and Ingbar, S. H. The effect of estrogens upon the peripheral metabolism of thyroxine. J. clin. Invest. 1960, 39, 1119.

9. Man, E. B., Heineman, M., Johnson, C. E., Leary, D. C., and Peters, J. P. The precipitable iodine of serum in normal pregnancy and its relation to abortions. J. clin. Invest. 1951, 30, 137.

10. Singh, B. P., and Morton, D. G. Blood proteinbound iodine determinations as a measure of thyroid function in normal pregnancy and threatened abortion. Amer. J. Obstet. Gynec. 1956, 72, 607.

11. Hon, E. H., and Morris, J. M. Gonadotropin titers in disturbed pregnancies. Surg. Gynec. Obstet. 1955, $101,59$.

12. Delfs, E., and Jones, G. E. S. Endocrine patterns in abortion. Obstet. gynec. Surv. 1948, 3, 680.

13. Russell, C. S., Paine, C. G., Coyle, M. G., and Dewhurst, C. S. Pregnanediol excretion in normal and abnormal pregnancy. J. Obstet. Gynaec. Brit. Emp. 1957, 64, 649.

14. Hon, E. H., and Morris, J. M. Evaluation of male Bufo americanus and Rana pipiens for pregnancy testing. Amer. J. Obstet. Gynec. 1956, 71, 331.

15. Zondek, B. Hormonal diagnosis of placental dysfunction leading to fetal death. Clin. Obstet. Gynec. 1960, 3, 1083.

16. Scott, K. G., and Reilly, W. A. Use of anionic exchange resin for the determination of protein-bound $\mathrm{I}^{131}$ in human plasma. Metabolism 1954, 3, 506.

17. Blanquet, P., Dunn, R. W., and Tobias, C. A. Isolation and quantitative estimation of iodide, thyroxine, and substances related to thyroxine by means of an anion exchange resin. Arch. Biochem. 1955, 58, 502.

18. Mitchell, M. L. Resin uptake of radiothyroxine in sera from non-pregnant and pregnant women. J. clin. Endocr. 1958, 18, 1437.

19. Sterling, K. and Tabachnick, M. Resin uptake of $\mathrm{I}^{131}$-triiodothyronine as a test of thyroid function. J. clin. Endocr. 1961, 21, 456.

20. Nicoloff, R. L., Nicoloff, J. T., and Dowling, J. T. Evaluation of vaginal smear, serum gonadotropin, PBI and thyroxine-binding as measures of placental adequacy. Clin. Res. 1960, 8, 111.

21. Braverman, L., and Ingbar, S. H. A rapid method for individually assessing hormonal binding by thyroxine-binding proteins. Clin. Res. 1961, 9, 176.

22. Ingbar, S. H. Pre-albumin: a thyroxine-binding protein of human plasma. Endocrinology 1958, $63,256$.

23. Ingbar, S. H. Clinical and physiological observations in a patient with an idiopathic decrease in the thyroxine-binding globulin of plasma. J. clin. Invest. 1961, 40, 2053.

24. Nicoloff, J. T., and Dowling, J. T. Idiopathic deficiency of serum thyroxine-binding in a eumetabolic adult. Clin. Res. 1961, 9, 74.

25. Beierwaltes, W. H., and Robbins, J. Familial increase in the thyroxine-binding sites in serum alpha globulin. J. clin. Invest. 1959, 38, 1683.

26. Florsheim, W. H., Dowling, J. T., Meister, L., and Bodfish, R. E. Familial elevation of serum thyroxine-binding globulins. J. clin. Endocr. 1962, 22, 735.

27. Hodgson, J. E. Office use of the frog test for pregnancy. J. Amer. med. Ass. 1953, 153, 271.

28. Benson, R. C., and Traut, H. F. The vaginal smear as a diagnostic and prognostic aid in abortion. J. clin. Endocr. 1950, 10, 675.

29. Berson, S. A., and Yalow, R. S. Quantitative aspects of iodine metabolism. The exchangeable organic iodine pool, and the rates of thyroidal secretion, peripheral degradation and fecal excretion of endogenously synthesized organically bound iodine. J. clin. Invest. 1954, 33, 1533.

30. Ingbar, S. H., and Freinkel, N. Simultaneous estimation of rates of thyroxine degradation and thyroid hormone synthesis. J. clin. Invest. 1955, 34, 808.

31. Sterling, K., and Chodos, R. B. Radiothyroxine turnover studies in myxedema, thyrotoxicosis, and hypermetabolism without endocrine disease. J. clin. Invest. 1956, 35, 806.

32. Robbins, J., and Rall, J. E. The interaction of thyroid hormones and protein in biological fluids. Recent Progr. Hormone Res. 1957, 13, 161.

33. Ingbar, S. H., and Freinkel, N. Thyroid hormones in Hormones in Human Plasma. Nature and Transport, H. N. Antoniades, Ed. Boston, Little, Brown, 1960, p. 515.

34. Simons, J. H. Statistical analysis of one thousand abortions. Amer. J. Obstet. Gynec. 1939, 37, 840.

35. Hertig, A. T., and Livingstone, R. G. Spontaneous, threatened and habitual abortions: their pathogenesis and treatment. New Engl. J. Med. 1944, 230, 797.

36. Hamblen, E. C. Some clinical observations on the endocrinology of abortion. Amer. J. Obstet. Gynec. 1941, 41, 664.

37. Malpas, P. A study of abortion sequences. J. Obstet. Gynaec. Brit. Emp. 1938, 45, 932.

38. Jones, G. E. S., and Delfs, E. Endocrine patterns in term pregnancies following abortion. J. Amer. med. Ass. 1951, 146, 1212.

39. Speert, H. Pregnancy prognosis following repeated abortion. Amer. J. Obstet. Gynec. 1954, 68, 665. 
40. Peterson, R. E. The miscible pool and turnover rate of adrenocortical steroids in man. Recent Progr. Hormone Res. 1959, 15, 231.

41. Chen, P. E., and Mill, I. H. in discussion of Peterson, R. E. The miscible pool and turnover rate of adrenocortical steroids in man. Recent Progr. Hormone Res. 1959, 15, 231.

42. Daughaday, W. H., Kozak, I., and Biederman, O. Corticosteroid binding globulin activity in body fluids and in fetal and maternal plasma (abstract). J. clin. Invest. 1959, 38, 998.
43. Russ, E. M., and Raymunt, J. Influence of estrogens on total serum copper and caeruloplasmin. Proc. Soc. exp. Biol. (N. Y.) 1956, 92, 465.

44. Fay, J., Cartwright, G. E., and Wintrobe, M. M. Studies on free erythrocyte protoporphyrin, serum iron, serum iron-binding capacity and plasma copper during normal pregnancy. J. clin. Invest. 1949, 28, 487.

45. Brody, S., and Carlström, G. Immuno-assay of human chorionic gonadotropin in normal and pathologic pregnancy. J. clin. Endocr. 1962, 22, 564. 